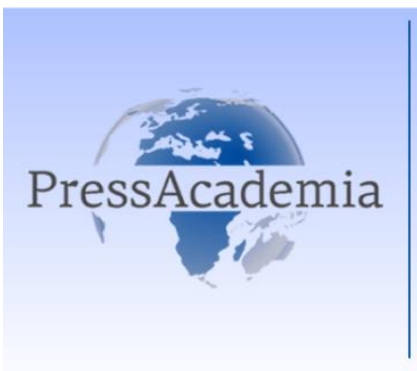

Press Academia Procedía

2nd World Conference on Technology, Innovation and Entrepreneurship

May 12- 14, 2017, Istanbul, Turkey. Edited by Sefer Şener

\title{
SIGNIFICANCE OF TECHNOLOGY-BASED ENVIRONMENT IN THE DEVELOPMENT OF NURSING STUDENTS' CRITICAL THINKING SKILLS
}

\author{
DOI: 10.17261/Pressacademia.2017.520 \\ PAP-WCTIE-V.4-2017(12)-p.74-79
}

\author{
Nur Guven Ozdemir ${ }^{1}$, Nuray Turan ${ }^{2}$, Hatice Kaya ${ }^{3}$ \\ ${ }^{1}$ Istanbul University, Florence Nightingale Nursing Faculty, Department of Fundamentals of Nursing, nur.guven@istanbul.edu.tr \\ ${ }^{2}$ Istanbul University, Florence Nightingale Nursing Faculty, Department of Fundamentals of Nursing, nkaraman@istanbul.edu.tr \\ ${ }^{3}$ Istanbul University, Florence Nightingale Nursing Faculty, Department of Fundamentals of Nursing, haticeka@istanbul.edu.tr
}

\begin{abstract}
In parallel with the increase of the students, there is a rapid increase use of technology. Wider accessibility to internet, use of e-mails, web sources, use of advanced mobile gadgets and simulators further fuels the use of technology. However, it is of crucial importance that technology-based learning environment has high-security hardware, that it embodies features that will properly suit their level of and help their development of cognitive, psychomotor and social development process of the students. Therefore, online class/labs and online applied conference/courses-when used effectively-will positively contribute to development of critical thinking skills, an indispensible part and major aim of contemporary education. Therefore, it is vital that technology-based learning environment is utilized and its significant is appreciated in order to enable development and actual practice of critical thinking skills by the nursing faculty members and the students.
\end{abstract}

Keywords: Technology-based learning environment, critical thinking, nursing, education JEL Codes: K12

\section{INTRODUCTION}

Health care systems are changing rapidly in many countries. As a result of these dynamic changes and developments experienced in health care systems, health care technologies have begun to develop rapidly (Cholewka and Mohr, 2009; Kala et al., 2010; Yoo and Park, 2014). This situation has led to the emergence of new knowledge and concepts related to technology in nursing education, practices and researches. In addition, it also required for nurses to acquire new knowledge and skills in the changing application areas (Camilli, 2014; Chan et al., 2016; Shellenbarger and Robb, 2015). Along with the global technological developments, nursing faculties providing education at the undergraduate level are faced with the fact that students should be prepared for the changing health care environments (Shellenbarger and Robb, 2015). Within the changing health care system, nurses are expected to have the necessary skills in health politics, leadership, system configuration, researches, evidence-based practices, team work and in their communication with other health care team members (Kala et al., 2010). However, nursing students may have difficulties in learning clinical skills including psychomotor, cognitive and affective domains (Haraldseid, 2015). Therefore, it is important for nursing students to use new teaching methods along with the changing technology in order to adapt to the changes and to implement nursing practices safely (Chlowka and Mohr, 2009). Since the knowledge level and clinical decision-making skills of the nurses are regarded as important factors in determining their professional competencies, instructors should develop learning methods to meet these learning requirements in nursing education (Kala et al., 2010). The education and training methods that are intertwined with technology can be used to reflect the theoretical knowledge on nursing practices. The use of technology in nursing education offers many advantages for developing new teaching strategies (Axley, 2008; Shellenbarger and Robb, 2015). It is very important to integrate information technologies into the curriculum so that nursing students can achieve success during their education and professional career (Edwars and O'Connor, 2011). The use of technology in nursing undergraduate courses is becoming widespread along with the ease of Internet access, the use of electronic mail and web resources, the development of mobile devices and simulators. The development of nursing students' critical thinking skills is 
ensured through the technology used, and they can easily make the right decisions and learn the theoretical and practical courses, and their adaptation to the clinical environment becomes easier (Carley, 2015; Doswell et al., 2013; Fitzgerald et al., 2012; Kaya et al., 2011).

Critical thinking is a mental process that enables the person to reach a decision that directs the individual's behavior a result of the active perception, analysis, synthesis and evaluation of the information obtained through observation, experience and communication, or all possibilities (Papathanasiou et al., 2014; Price 2015; Pucer et al. 2014). Critical thinking, which is an important element of the education process, develops with knowledge and experience (Kaddoura, 2011; Porter-O'Grady et al., 2005). Graduated nurses are expected to have critical thinking skills to ensure their compliance with the multidimensional care systems that include complexity of service offered in various fields, technological knowledge and application and with the rapidly changing health care systems (Chan et al. 2016; Kaya et al., 2011; Shirrell 2008). Nurses use critical thinking skills while taking important decisions about the solution of different problems they encounter during working hours and the stress caused by these problems. Critical thinking, which is an important part of occupational responsibility and nursing care, ensures that nurses perform more evidence-based practices while providing to achieve the expected results in patient care (Benner et al. 2008; Chan 2013; Kaya et al., 2011; Papathanasiou et al. 2007; Pucer et. al. 2014). When the literature is examined, it is seen that technological developments such as simulation applications, distance education techniques, online applied conferences and courses, mobile devices that have been used in nursing education in recent years are effective in the development of their critical thinking and decision making skills (Pucer et. al. 2014; Reviriego 2014; Wu 2014).

\section{DISTANCE EDUCATION TECHNOLOGIES}

Distance education is defined as the process of ensuring that nursing students receive education outside the classroom or the building where education is provided, ensuring the learning of more people, and offering an opportunity to share educational and teaching resources with the students, along with the integrated use of video, audio, computer, email, fax, multimedia communication or other technological methods (Kantek, 2013; Mancusa, 2009).

In parallel with the increase in content of the scientific knowledge that guides nursing practices, the intensity of the subjects in the nursing curriculum and course contents is increasing. In addition, in line with the increasing demand for higher education institutions, the number of students is increasing with each passing day, and changes are seen in the demographic characteristics of the students such as the average age and working conditions (Holly, 2009; Kaveevivitchai et al., 2009; Kummerow, 2009). This situation causes troubles for institutions in terms of the fact that economic, political, physical working conditions and the number of instructors are insufficient (Şenyuva and Taşocak, 2014). All these factors lead to the necessity of using and developing distance education technologies in order to prevent time limitations in training applications, to reduce content intensity and to provide training for more learners (Carpenter et al., 2013; Kummerow, 2009; Mee, 2014). Thanks to distance education technologies, students and instructors can learn in different environments and at different times, even in different countries (Holly, 2009).

Nursing education in distance education systems has been mentioned since 1969 (Kala et al., 2010). While web-based computer technologies that were used during the first years of distance education in nursing education were used only in the education and learning process, they are now being used as a strategy for sharing learning skills and knowledge (Kala et al., 2010). Distance education is an important training method used to enable students to receive nursing education flexibly and to follow new developments in the changing and developing health system, without the requirement of attending the courses. However, in order for these training methods to be carried out effectively, the educational institutions should have adequate technological facilities, experienced instructors, technical staff and structured programs (Kummerow, 2009; Seven et al., 2014). American Association of Colleges of Nursing (AACN) (1999) states that distance education techniques will ensure nurses' preparation of clinical practices and contribute to the education of future nurse lecturers when they are used with caution (Mancusa, 2009). When distance education technologies are managed well, they provide effective and fast feedback by facilitating the interaction between students and instructors and their peers. This situation enables students to develop their critical thinking skills (Carter et al., 2006).

Critical thinking skill is a part of distance education, and it is important for students to think critically during the learning experience or to acquire the necessary skills (Gharip et al., 2016). Nurses with critical thinking skills can respond to their practices more effectively in order to meet the needs of the healthy/sick individual (Carter et al., 2006).

\subsection{Simulation Technologies}

Simulation is accepted as a valid tool by instructors and researchers in the acquisition of knowledge and is used as an innovative teaching approach. When it is accepted as a learning tool, simulation is in good harmony with the theoretical and conceptual structure of nursing education (Campbell and Daley, 2013; Faulcon, 2015). Students' experiences on patient care and ability to deal with problems may be inadequate due to the rapid changes in application areas, problems related 
to patient safety and ethical problems. It is very important that health professionals are prepared to provide fast, safe and effective care in the presentation of health care. For this purpose, simulation is used as an approach to provide active and experiential learning (Clayton et al., 2017; Kim et al., 2016).

Simulation technologies offer opportunities to present and learn nursing practices in a realistic environment. Instructors use low-tech simulations (low fidelity simulations) such as arm models and hip models and simulations including advanced technology supported by computer systems (screen based simulations) to prevent patients from being harmed by reducing medical errors. Students are learning care practices by performing all possible errors on simulation models without harming the patients (Faulcon 2015; Lavoie and Clarke, 2017; Solnick and Weiss, 2007). On the other hand, students develop their clinical decision making skills by means of simulation applications, their self-confidence increases, and also their problem solving and communication skills develop (Sharoff, 2013). Thanks to the realistic simulation scenarios, all inexperienced or expert nurses and students can acquire the skills necessary to fulfill the roles and responsibilities expected from them in life-threatening situations and emergency situations. However, while simulation technologies are integrated into the nursing curriculum by faculties, it is necessary to evaluate their advantages, disadvantages, difficulties and whether they meet the learning outcomes (Faulcon, 2015). In addition, the content and the difficulty level of the scenarios, and students' learning requirements should be evaluated during the planning of simulation scenarios. These scenarios should not cause too much stress on students (Kim et al., 2016; Clayton et al., 2017).

Nursing education studies have shown that simulation technologies make it easier for students to learn application skills, support critical thinking and their confidence level and increase their scientific knowledge (Sharoff, 2013). Critical thinking has been emphasized as a standard at all levels of education from the past to the present day. Simulation completes the missing pieces for nursing education by transforming the enthusiasm that every student has in technology into an interactive and valuable learning that focuses on critical thinking (Radhakrishnan et al., 2007). The fact that simulation technologies are ethically appropriate and that nursing practices are also applied in a safe, effective and ethical manner contribute to the integration of nursing students with theoretical knowledge and critical thinking (Campbell and Daley, 2013)

\subsection{Mobile Technologies}

Mobile technologies started to be used in nursing education about 20 years ago (Swan et. al. 2013). In the literature, concepts such as PDA-personal digital assistants, smart phones, tablets, handheld terminals are used to describe mobile devices (Doyle et al. 2014). Mobile technologies have become significant in the healthcare environment since they enable nursing students to get information about medicines, patient care and diseases (Day-Black and Merril, 2015). The use of mobile devices in health education becomes even more important due to inadequate number of educators and the increase in the number of formal and evening education students enrolled in nursing faculties (Maag 2006). Nursing students are encouraged to use mobile devices to monitor their recorded practices, to access information resources related to the subject, to use technological products related to care practices, and to know the existence of these technologies and to comply with them (Doyle et al. 2014).

In nursing education, mobile technologies are used in clinical applications, classes and practice/simulation laboratories (Raman 2015). The complexity of the issues related to healthy/sick individual's health is faced with the fact that increasingly effective clinical information should be managed (Dolye et al. 2014). The use of mobile learning applications by educators is increasing to facilitate and improve the learning of students in the field of health sciences, to provide rapid communication and interaction with evidence-based applications. Thus, instructors can observe students' progress thanks to mobile technologies (Coulby et al. 2011; George et. al. 2010; Maag 2006). While these advantages are provided in terms of educators, students are provided with advantages in issues such as quick access to information, providing cognitive and collaborative learning, getting feedback from educators more often (Coulby et al. 2011; Kenny et al. 2009; Wyatt 2010). Mobile devices provide quick access to desired evidence-based information about nursing practices and also support students' critical thinking and decision-making processes (Doran et al. 2010; Lai and Wu 2012). In the study carried out by Lai and Wu (2012) with 8 students in psychiatry clinics for 3 weeks, they determined that the combination of mobile technologies and internet technologies is effective in the development of students' critical thinking skills. This situation is effective for students to plan the care of the healthy/sick individual in a way specific to individual, and supporting individuality (Sedgwick 2016)

\section{CONCLUSION}

The expansion of technology in nursing education has an important role for students to acquire the professional knowledge and skills required by the age. The distance education used in nursing education will start to be used more in the education of students along with the advancement of technological developments such as simulation and mobile technologies. 
Graduate nurses should receive education by closely following the technological developments to fulfill their professional roles and responsibilities defined in the international arena and to be able to think critically while making decisions about patient care in the clinical environment. Accordingly, the fact that institutions increase their technological equipments and provide the physical conditions by being supported politically and economically by the governments for nursing education, the participation of instructors and students in trainings (congress, symposium, seminar etc.) for the effective and ethical use of technological equipment, and increasing the number of researches evaluating the effectiveness of technology in care are important. When all these possibilities are provided, students will closely follow the developments in the field of health care by developing their high-level learning and critical thinking skills, and the results expected in the care of a healthy/sick individual and patient safety will be ensured.

\section{REFERENCES}

Benner, P., Hughes, R. \& Sutphen, M. 2008, “Clinical Reasoning, Decision Making, and Action: Thinking Clinically and Critically", R. G. Hughes (Ed.), Patient Safety and Quality: An Evidence-Based Handbook for Nurses, Agency for Healthcare Research and Quality, pp. 1-23.

Camilli, S.A. 2014, "Plugging into Nursing Informatics: Preparation, Practice,and Beyond", Canadian Journal of Nursing Informatics, volume 9, no $1 \& 2$, pp. 1-9.

Campbell, S.H., Daley, K.M. 2013, "Simulation-Focused Pedagogy for Nusing Education", S.H. Campbell and K.M. Daley (Eds.), Simulation Scenarios for Nursing Educators, 2nd Editon, Springer Publishing Company, pp. 1-7.

Carley, A. 2015, “Using Technology to Enhance Nurse Practioner Student Engagement”, The Nurse Practitioner, vol. 40, no. 7, pp.47-54.

Carpenter, R.,Theeke, L., Smothers, A. 2013, "Enhancing Course Grades and Evaluations Using Distance Education Technologies", Nurse Educator, vol. 38, no. 3, pp. 114-117.

Carter, L., Rukholm, E., Mossey, S., Viverais-Dresler, G., Bakker, D., Sheehan, C. 2006, “Critical Thinking in the Online Nursing Education Setting: Raising the Bar", Canadian Journal of University Continuing Education, vol. 32, no. 1, pp. 27-46.

Chan, Z.C.Y. 2013, “A Systematic Review of Critical Thinking in Nursing Education”,Nurse Education Today, vol. 33, pp. 236-240.

Chan, A. W.K., Chair, S.Y., Sit, J. W.H., Wong, E. M.L., Lee, D. T.F., Fung O. W.M. 2016, "Case-Based Web Learning Versus Face-to-Face Learning: A Mixed-Method Study on University Nursing Students", The Journal of Nursing Research, vol. 24, no. 1, pp. 31-40.

Cholewka, P.A., Mohr, B. 2009, “Enhancing Nursing Informatics Competencies and Critical Thinking Skills Using Wireless Clinical Simulation Laboratories", Studies in Health Technology and Informatics, vol. 146, pp. 561-563.

Clayton, M. F., Supiano, K., Wilson, R., Lassche, M., Latendresse, G. 2017, “Using Simulation in Nursing Phd Education: Facilitating Application of Responsible Conduct of Research Principles", Journal of Professional Nursing, vol 33, no. 1, pp. 68-73.

Coulby, C., Hennessey, S., Davies, N., Fuller, R. 2011, "The Use of Mobile Technology for Work-Based Assessment: The Student Experience", British Journal of Educational Technology, vol. 42, no. 2, pp. 251-265.

Day-Black, C., Merrill, E.B. 2015, “Using Mobile Devices in Nursing Education”, The ABNF Journal, vol. 26, no. 4, pp. 78-84.

Doran, D.M., Haynes, R.B., Kushniruk, A., Straus, S., Grimshaw, J., McGillis-Hall, L.,Dubrowski, A., Di Pietro, T., Newman, K., Almost, J., Nguyen, H., Carryer, J., Jedras, D., 2010, "Supporting Evidence-Based Practice for Nurses through Information Technologies", Worldviews Evidence-Based Nursing, vol. 7, pp. 4-15.

Doswell, W., Braxter, B. Dabbs, A. D., Nilsen, W. Klem M. L. 2013, "mhealth: Technology for Nursing Practice, Education, and Research", Journal of Nursing Education and Practice, 2013, vol. 3, no. 10, pp. 99-109.

Doyle, G.J., Garrett, B., Currie, L.M., 2014, “Integrating Mobile Devices into Nursing Curricula: Opportunities for Implementation Using Rogers' Diffusion of Innovation Model", Nurse Eduction Today, vol. 34, 775-752.

Edwards, J., O'Connor, P.A. 2011, "Improving Technological Competency in Nursing Students: The Passport Project", The Journal of Educators Online, volume 8, number 2, pp.1-20.

Faulcon, R.Y. 2015, “Innovative Teaching Strategies with Simulation Technology in Nursing Education”, Journal of Bermuda College, vol.1, pp. 47-50.

Fitzgerald, C., Kantrowitz-Gordon, I., Katz, J. Hirsch, A. 2012, "Advanced Practice Nursing Education: Challenges and Strategies", Nursing Research and Practice, Nursing Research and Practice, vol. 12, pp. 1-8.

George, L.E., Davidson, L.J., Serapiglia, C.P., Barla, S., Thotakura, A., 2010, "Technology in Nursing Education: A Study of PDA Use by Students", Journal of Professional Nursing, vol.26, no.6, pp. 371-376.

Gharib, M., Zolfaghari, M., Mojtahedzadeh, R., Mohammadi, A., Gharib, A. 2016, "Promotion of Critical Thinking in E-Learning: A Qualitative Study on The Experiences of Instructors and Students", Advances in Medical Education and Practice, vol. 7, pp. 271-279. 
Haraldseid, C., Friberg, F., Aase, K. 2015, “Nursing Students' Perceptions of Factors Influencing Their Learning Environment in a Clinical Skills Laboratory: A Qualitative Study", Nurse Education Today, vol. 35, pp. e1-e6.

Holly, C. 2009, "The Case for Distance Education in Nursing", Journal of Online Learning and Teaching, vol. 5, no. 3, pp. 506-510.

Kaddoura, M. A. 2011, "Critical Thinking Skills of Nursing Students in Lecture-Based Teaching and Case-Based Learning,", International Journal for the Scholarship of Teaching and Learning, vol. 5: no. 2, pp. 1-18.

Kala, S., Isaramalai, S., Pohthong, A. 2010, "Electronic Learning and Constructivism: A Model for Nursing Education", Nurse Education Today, vol. 30, pp. 61-66.

Kaya, N, Bolol, N, Turan, N, Kaya, H, İş̧i, Ç. (2011, “Kulak Burun Boğaz Kliniklerinde Çalışan Hemşirelerin Karar Verme Stratejileri ve Mesleki Doyumları (Decision-making Strategies and Professional Satisfaction of Nurses Working in Ear Nose Throat Clinics) ", Firat Tıp Dergisi (Firat Medical Journal), vol. 16, no.1, pp.25-31.

Kaveevivitchai, C., Chuengkriankrai, B., Luecha,Y., Thanooruk, R., Panijpan , B., Ruenwongsa, P. 2009, “Enhancing Nursing Students' Skills in Vital Signs Assessment by Using Multimedia Computer-Assisted Learning with Integrated Content of Anatomy and Physiology" Nurse Education Today, vol. 29, pp. 65-72.

Kenny, R.F., Park, C., Neste-Kenny, J.M.C.V., Burton, P.A.,Meiers, J. 2009, “Using Mobile Learning to Enhance Quality of Nursing Practice Education", M. Ally (Ed.), Mobile Learning Transforming the Delivery of Education and Training, AU Press, pp. 75-98.

Kim, J., Park, J.H., Shin, S. 2016, "Effectiveness of Simulation-Based Nursing Education Depending on Fidelity: A Metaanalysis", BMC Medical Education, vol.16, pp.152-159.

Lai, C.Y., Wu, C.C. 2012, "Supporting Nursing Students' Critical Thinking with a Mobile Web Learning Environment", Nurse Educator, vol. 37, no. 6 , pp. 235-236.

Lavoie, P., Clarke,S. P. 2017, “Simulation in Nursing Education”, Nursing Management, vol. 48, no. 2, pp. 16-17.

Maag, M. (2006). "Ipod, Upod? An Emerging Mobile Learning Tool in Nursing Education and Students' Satisfaction". L. Markauskaite, P. Goodyear, P. Reimann (Eds.), Proceedings of the 23rd Annual ascilite conference: Who's Learning? Whose Technology, Sydney University Press, pp. 483-492.

Mancuso, J.M. 2009, "Perceptions of Distance Education among Nursing Faculty Members in North America", Nursing and Health Sciences, vol. 11, pp. 194-205.

Mee, S. 2014, "Is Distance Education the Answer to the Nursing Shortage?”, Open Journal of Nursing, vol. 4, pp. 158-162.

Papathanasiou, I., Kotrotsiou, S., Bletsa, V. 2007, "Nursing Documentation and Recording Systems of Nursing Care", Health Science Journal, vol. 1, no.4.

Papathanasiou, I. V., Kleisiaris, C. F., Fradelos, E. C., Kakou, K., Kourkouta, L. 2014, “Critical Thinking: The Development of an Essential Skill for Nursing Students", Acta Informatica Medica, vol. 22, no.4, pp. 283-286.

Porter-O'Grady, T., Igein, G., Alexander, D., Blaylock, B., McComb, D., Williams, S., 2005, “Critical Thinking for Nursing Leadership”, Nurse Leader, pp. 28-31.

Price, B. 2015, “Applying Critical Thinking to Nursing” Nursing Standard, vol. 29, no. 51, pp. 49-58.

Pucer, P., Trobec, I., Žvanut, B. 2014, “An İnformation Communication Technology Based Approach for The Acquisition of Critical Thinking Skills", Nurse Education Today, vol. 34, 964-970.

Radhakrishnan, K., Roche, J.P., Cunnigham, H. 2007, “Measuring Clinical Practice Parameters with Human Patient Simulators: A Pilot Study", International Journal of Nursing Education Schorship, vol. 4, no.1, pp. 1-10.

Raman, J. 2015, "Mobile Technology in Nursing Education: Where Do We Go From Here? A Review Of The Literature", Nurse Education Today, vol. 35, pp. 663-672.

Reviriego, E., Cidoncha, M. Á., Asua, J., Gagnon, M. P., Mateos, M., Gárate L., de Lorenzo, E., González, R. M. 2014, “Online Training Course on Critical Appraisal for Nurses: Adaptation and Assessment", BMC Medical Education, vol. 14, pp. 1-10.

Seven, M., Çınar, F.İ., Fidancı, B.E., Akyüz, A., 2014, "Nurses' Perspective of Distance Post-Graduate Education: A Turkish Study", International Journal of Caring Sciences, vol 7, no 2, pp. 652-661.

Sharoff, L. 2013, "Simulation and Learning to Care for Patients: Acute Alcohol Withdrawal", Journal of Contemporary Medicine, vol. 3, no. 1, pp. 22-27.

Shellenbarger, T., Robb, M. 2015, "Technology-Based Strategies for Promoting Clinical Reasoning Skills in Nursing Education", Nurse Educator, vol. 40 , no. 2, pp. 79-82.

Shirrell, D. 2008, "Critical Thinking as a Predictor of Success in an Associate Degree Nursing Program", Teaching and Learning in Nursing, vol. 3 , no.4, pp. 131-136. 
Solnick, A., Weiss, S., 2007. "High Fidelity Simulation in Nursing Education: A Review of the Literature", Clinical Simulation in Nursing Education, vol. 3, pp. e41-e45.

Swan, B.A., Smith, K.A., Frisby, A., Shaffer, K., Hanson-Zalot, M., Becker, J., 2013., "Evaluating Tablet Technology in an Undergraduate Nursing Program", Nursing Education Perspectives, vol.34, no.3 ,pp. 192-193.

Şenyuva, E., Taşocak, G. 2014, "Implementation of Web-Based Distance Education in Nursing Education in Turkey: A Sample Lesson in Patient Education", International Journal of Distance Education Technologies, vol. 12 no.3, pp. 1-13.

Wu, T.T. 2014, "Using Smart Mobile Devices in Social-Network-Based Health Educationpractice: A Learning Behavior Analysis", Nurse Education Today, vol. 34, pp. 958-963.

Wyatt, T.H., Krasukopf, P.B., Gaylord, N.M., Ward, A., Huffstutler-Hawkins, S., Goodwin, L. 2010, “Cooperative M-Learning with Nurse Practitioner Students", Nursing Education Perspectives, vol. 31, no.2, pp. 109-113.

Yoo, M.S., Park, J.H. 2014, “Effect of case-based learning on the development of graduate nurses' problem-solving ability”, Nurse Education Today, vol. 34, pp. 47-51. 